\title{
A regulatory circuit between Kaposi sarcoma- associated herpesvirus and host innate immune system
}

Luwen Zhang

\author{
From 13th International Conference on Malignancies in AIDS and Other Acquired Immunodeficiencies \\ (ICMAOI) \\ Bethesda, MD, USA. 7-8 November 2011
}

Kaposi sarcoma-associated herpesvirus (KSHV) is a human $\gamma$-herpesvirus associated with several human malignancies. The replication and transcription activator (RTA) is necessary and sufficient for the switch from KSHV latency to lytic replication. Toll-interleukin-1 receptor (TIR) domain-containing adaptor-inducing $\beta$-interferon (TRIF, also called TIR-domain-containing adaptor molecule-1 (TICAM-1)) is a signaling adaptor molecule that is critically involved in the Toll-like receptor 3 (TLR3) and TLR-4 signaling pathways for type I interferon (IFN) production, a key component of innate immunity against microbial infection. Previously we have identified that RTA blocks TLR3 signaling activation by degrading cellular TRIF, and this RTA-mediated degradation is at least partially mediated through the ubiquitin-proteasome pathway. In this report, we have identified a new mechanism that innate immunity regulates KSHV replication. We find that TRIF increases the expression of KSHV RTA. The enhancement of RTA expression and the degradation of TRIF are two independent pathways. TRIF specifically enhances the translation efficiency of RTA mRNA. Because RTA may not directly interact with TRIF, the functional interactions between TRIF and RTA may be indirect through unknown mediators. Taken together, these data suggest that KSHV employs a novel mechanism to block the innate immunity by degrading TRIF protein, and at the same time, use the innate immune system to boost viral replication by increasing the expression of KSHV RTA. This regulatory circuit may be an important part of the KSHV-host interactions for the initial infections. This work may contribute to our understandings on

Correspondence: zhang2@unlnotes.unl.edu

School of Biological Sciences, Nebraska Center for Virology, University of Nebraska, Lincoln, NE, USA how KSHV interacts with the host immune system for its survival in vivo.

Published: 19 April 2012

\section{doi:10.1186/1750-9378-7-S1-P28}

Cite this article as: Zhang: A regulatory circuit between Kaposi

sarcoma-associated herpesvirus and host innate immune system. Infectious Agents and Cancer 2012 7(Suppl 1):P28.
Submit your next manuscript to BioMed Central and take full advantage of:

- Convenient online submission

- Thorough peer review

- No space constraints or color figure charges

- Immediate publication on acceptance

- Inclusion in PubMed, CAS, Scopus and Google Scholar

- Research which is freely available for redistribution
C Biomed Central
C Biomed Central

(c) 2012 Zhang; licensee BioMed Central Ltd. This is an Open Access article distributed under the terms of the Creative Commons Attribution License (http://creativecommons.org/licenses/by/2.0), which permits unrestricted use, distribution, and reproduction in any medium, provided the original work is properly cited. 